\title{
Seismic Behavior of Posttensioned Concrete Bridge Piers with External Viscoelastic Dampers
}

\author{
Anxin Guo and Huixing Gao \\ Ministry-of-Education Key Laboratory of Structural Dynamic Behavior and Control, School of Civil Engineering, \\ Harbin Institute of Technology, Harbin 150090, China \\ Correspondence should be addressed to Anxin Guo; guoanxin@hit.edu.cn
}

Received 15 December 2015; Revised 15 March 2016; Accepted 16 March 2016

Academic Editor: Kenneth J. Loh

Copyright (c) 2016 A. Guo and H. Gao. This is an open access article distributed under the Creative Commons Attribution License, which permits unrestricted use, distribution, and reproduction in any medium, provided the original work is properly cited.

\begin{abstract}
This paper investigates the seismic performance of posttensioned concrete piers with external viscoelastic dampers to improve the energy dissipation capacity of this type of structure. An installation scheme for viscoelastic dampers on bridge piers is proposed, and the mechanical models of the damper are analyzed according to the installation scheme. By attaching the viscoelastic dampers to the posttensioned bridge piers, the analytical model of the hybrid system is established using the OpenSees finite element analysis package. Cyclic behavior and time history analyses are conducted on a posttensioned bridge with and without viscoelastic dampers using the established finite element model. The analysis results indicate that the viscoelastic dampers can effectively improve the seismic performance of the bridge structures with posttensioned piers.
\end{abstract}

\section{Introduction}

Residual displacement is a common seismic damage mode in conventional bridge piers. Because the residual displacement of bridge piers hinders emergency rescue efforts and increases the repair costs after earthquakes, researchers have recognized the importance of developing a hybrid system to achieve self-centering capacity by combining segmental piers with pretensioned tendons. In 1993, Priestley et al. [1, 2] proposed the concept of employing unbounded posttensioned tendons, which provided a restoring force on the piers, to achieve immediate recoverability of the structures following large earthquakes.

Following that, a number of analytical and experimental studies were performed to investigate the self-centering properties of the concrete piers with unbonded or partially bonded prestressed tendons under earthquake excitations. Among them, the monotonic behavior of the unbonded posttensioned bridge piers under increasing lateral force or displacement was analyzed by using the finite element method to understand the strength, stiffness, and ductility characteristics of the structural system $[3,4]$. The hysteretic characteristics of the self-centering bridge piers were also widely investigated through both numerical simulation under cyclic loads and quasistatic tests. The analytical and experimental test results by Hewes and Priestley [5], Chou and Chen [6], and Pinto et al. [7] revealed that bridge piers with prestressed tendons could effectively resist the lateral cyclic load with sufficient strength while maintaining smaller residual displacement under large lateral deformation.

For bridge piers with unbonded posttensioned tendons, the seismic responses of the self-centering structures can be analyzed by using the nonlinear single-degree-of-freedom model through the idealized hysteretic curve based on cyclic behavior analysis and tests [1]. However, the time history analysis based on the finite element method, especially employing the fiber element to model the columns or piers, is more widely accepted for exploiting the seismic performance of the hybrid system [8]. To validate the analysis methods and design theories, Cheng [9] and Jeong et al. [10] conducted shaking table tests on self-centering reinforced concrete bridge columns. The experimental results by Cheng [9] demonstrated that the bridge model could rock up to $5 \%$ of the column rotation without damage or residual displacement. In addition, given the increasing interest in self-centering bridge piers, Wacker et al. [11] and Lee and Billington [12] also developed design procedures 


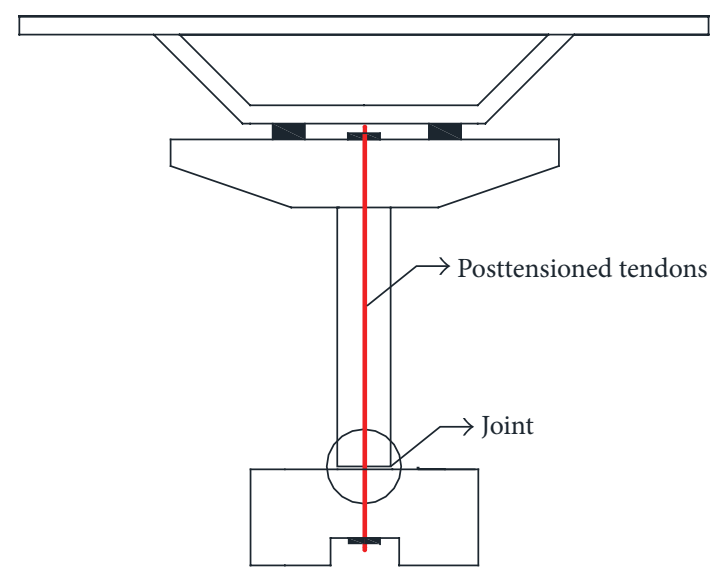

(a)

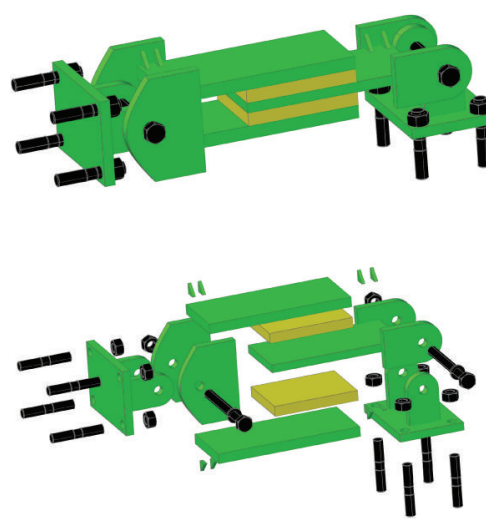

(b)

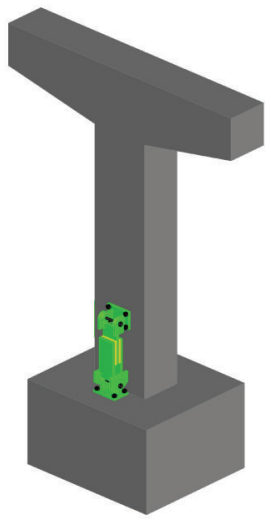

(c)

FIGURE 1: Schematic diagram of the self-centering bridge piers: (a) common self-centering bridge with posttensioned tendons; (b) configuration of the viscoelastic damper; (c) installation scheme of the viscoelastic dampers.

and a seismic assessment method based on the performancebased earthquake engineering framework.

Whereas self-centering structures with posttensioned tendons exhibit high performance for eliminating residual displacement, it is also found that this type of structure contains inherent defects of low energy dissipation, which increases the seismic responses of the structures. Setting external dampers outside the bridge columns is an innovative technology to improve the seismic performance of such structures. To improve the energy dissipation capacity, Palermo et al. [13] used internal unbonded mild-steel reinforcement as the dissipater. The monotonic and cyclic behaviors of the joint hybrid system with self-centering and dissipation capacity were analyzed and experimentally validated through five $1: 3$ scaled bridge pier specimens. Ou et al. [14] proposed the method of using high-performance steel reinforcing bars as internal energy dissipation components of precast segmental bridge piers. The cyclic behavior has been experimentally investigated and compared with the conventional energy dissipation bars. The results indicated that the residual displacement would not be larger than $1 \%$ if the shear resistance provided by energy dissipation bar is below $35 \%$ in segmental bridge columns. Marriott et al. $[15,16]$ employed external replaceable mild-steel dissipaters to improve the energy dissipation capacity of posttensioned rocking bridge piers. The uniaxial and biaxial cyclic tests revealed that the hybrid system exhibits better stability, energy dissipation, and recentering capacities. However, the structural performance was significantly reduced under the biaxial loads compared with that under the uniaxial loadings. However, some researchers have also explored the use of concrete-filled steel tubes [6] or fiber-reinforced polymer (FRP) tubes [17] to enhance the ductility of the self-centering piers.

As described above, the self-centering piers generally consist of the bridge column, unbonded posttensioned tendons, and internal or external mild-steel reinforced bars for energy dissipation. Although the internal mild-steel dissipaters can increase the damping of the structures, the internal design scheme will make the repair or replacement of the dissipaters more difficult after earthquake events because of the nonlinear deformation and performance deterioration of the reinforced bars during the energy dissipation process. Alternatively, the external mild-steel dissipaters proposed in recent years could avoid those defects of the hybrid system. However, some passive energy dissipaters that have been widely used in the vibration control of building structures, such as viscous damper, viscoelastic damper, friction damper, and shape memory alloy dampers, can also be selected as the alternative energy dissipater for this type of structure.

This paper explores the possibility and effectiveness of viscoelastic dampers for enhancing the seismic performance of the self-centering bridge with posttensioned tendons. First, the installation scheme of the viscoelastic damper is proposed. Considering the deformation status of the viscoelastic dampers, the mechanical models of the viscoelastic dampers are proposed for the earthquake ground motions in the longitudinal and transverse directions, respectively. The finite element model of the hybrid system with posttensioned tendons and viscoelastic dampers is established by using the OpenSees software package. A numerical simulation is conducted to validate the effectiveness of the proposed hybrid system. From the cyclic behavior and the time history analysis, it is observed that the viscoelasticity can effectively mitigate the seismic responses of the bridge with posttensioned self-centering bridge piers.

\section{Installation Scheme and Mechanical Models of Viscoelastic Damper}

2.1. Configuration of the Self-Centering Bridge Pier with Posttensioned Tendons. Figure 1(a) shows the schematic diagram of the common self-centering bridge pier equipped with posttensioned tendons. For this type of hybrid structure, the bottom of the pier is separated from the foundation, and posttensioned tendons with initial strain are adopted to generate the recentering lateral force. During the seismic events, the structure sustains the gravity loads and the seismic-induced 
lateral inertia force. Owing to the noncontinuity between the bridge pier and foundation, the bridge pier achieves the ability of self-centering under the combination of the gravity loads and the tension force generated by the posttensioned tendons. Generally, the hybrid bridge pier has the potential for flexural failure with gap opening and shear slip failure between the pier and foundation under the lateral loads. Among them, the shear slip of the hybrid piers should be avoided owing to the irreversibility through appropriate design, such as setting a spherical ball-and-socket located at the center of the section given in [16]. Therefore, the shear slip failure of the hybrid piers is not included in the numerical simulation of this study.

2.2. Installation Scheme of the Viscoelastic Dampers. It is well known that self-centering bridge piers generally sustain small structural damage owing to the noncontinuous joint between the piers and foundation and the posttensioned tendons. However, this type of structure has very narrow flag-shape hysteretic characteristics, achieving a minor level of hysteretic damping under seismic excitations. To increase the damping of the structures, viscoelastic dampers are proposed to be employed as the external dissipater. The suggested configuration of the viscoelastic damper used in this study is shown in Figure 1(b). It is observed that this configuration of the energy-dissipated device is similar to the conventional viscoelastic dampers with several sandwich layers of viscoelastic material and steel plates. One-way hinges are set at both ends of the damper. The installation scheme of the damper attached to the pier is depicted in Figure 1(c). It is observed that the viscoelastic dampers are installed at the bottom of the piers. One hinge is connected with the foundation, and the other is fixed on the column.

It can be found from the figure that the viscoelastic dampers sustain the axial tension force only if the earthquake ground motion is propagated along the longitudinal direction owing to the function of the hinges. In this case, the viscoelastic material between the outer steel flanges and the center plate is subjected only to pure shear deformation under the external earthquake ground motions. However, if the earthquake excitation attacks the bridge structure along the transverse direction, the viscoelastic damper would move together with the deformation of the pier, resulting in the torsion of the viscoelastic material between the inner and outer steel plates.

2.3. Mechanical Properties of the Viscoelastic Damper. In the following, the mechanical model of the viscoelastic damper under the two different deformation cases is analyzed. In the case of pure shear deformation of the viscoelastic material, the corresponding force-displacement relationship can be written in the common form as

$$
F(t)=k_{F} x_{F}(t)+c_{F} \dot{x}_{F}(t),
$$

where $F(t)$ is the control force generated by the viscoelastic damper; $k_{F}$ and $c_{F}$ are the equivalent stiffness and damping of the dampers, respectively; and $x_{F}(t)$ and $\dot{x}_{F}(t)$ are the relative displacement and velocity, respectively, between the outer and inner steel plates. In the above equation, the equivalent stiffness and damping of the damper can be calculated by

$$
\begin{aligned}
& k_{F}=\frac{n A G^{\prime}(\omega)}{h}, \\
& c_{F}=\frac{n A G^{\prime \prime}(\omega)}{\omega h},
\end{aligned}
$$

where $n$ is the number of viscoelastic material layers; $G^{\prime}(\omega)$ and $G^{\prime \prime}(\omega)$ are the shear storage modulus and shear loss modulus of the viscoelastic material, respectively; and $A$ and $h$ are the area and thickness, respectively, of the viscoelastic material bonded between two neighboring steel plates.

When the earthquake attacks the pier along the transverse direction of the damper, the hinge attached to the bridge pier will move together with the pier, consequently sustaining the rotation and imposing additional moment on the piers. The schematic diagram of the mechanical model of the viscoelastic damper in this case is shown in Figure 2. For simplicity, the posttensioned tendons are not depicted in this figure. It is observed that the longitudinal steel reinforcement of the selfcentering piers does not extend into the foundation. When the earthquake excitations are exerted on the structure, they will induce the gap opening of the joint and noncontinuous interface between the column and footing. Under seismic excitations, the hinge attached to the piers will simultaneously move with the structures, whereas the bottom hinge is rigidly fixed with the footing. In this case, the deformation of the viscoelastic damper can be decoupled into the horizontal and vertical deformation and the rotation around the center of the dampers.

The outer steel flange attached with the pier is assumed to be rigid. In accordance with the relationship between the movement of the pier and the viscoelastic damper, the deformation at the center of the damper can be obtained as

$$
\begin{aligned}
& x_{F}=x_{p}+r \sin \theta_{p}, \\
& y_{F}=y_{P}-r\left(1+\cos \theta_{P}\right), \\
& \theta_{F}=\theta_{P},
\end{aligned}
$$

where $x_{P}, y_{P}$, and $\theta_{P}$ are the horizontal and vertical deformations and rotation of the pier at point $P$, respectively; $x_{F}$, $y_{F}$, and $\theta_{F}$ are the corresponding deformations and rotation of the damper; and $r$ is the length between the center of the damper and the hinge.

According to the above deformation relationship between the pier and damper, the horizontal and the vertical control forces generated by the device can be easily written as

$$
\begin{aligned}
& F_{x}=\frac{n G^{\prime}(\omega) A}{h} x_{F}+\frac{n G^{\prime \prime}(\omega) A}{\omega h} \dot{x}_{F}, \\
& F_{y}=\frac{n G^{\prime}(\omega) A}{h} y_{F}+\frac{n G^{\prime \prime}(\omega) A}{\omega h} \dot{y}_{F} .
\end{aligned}
$$




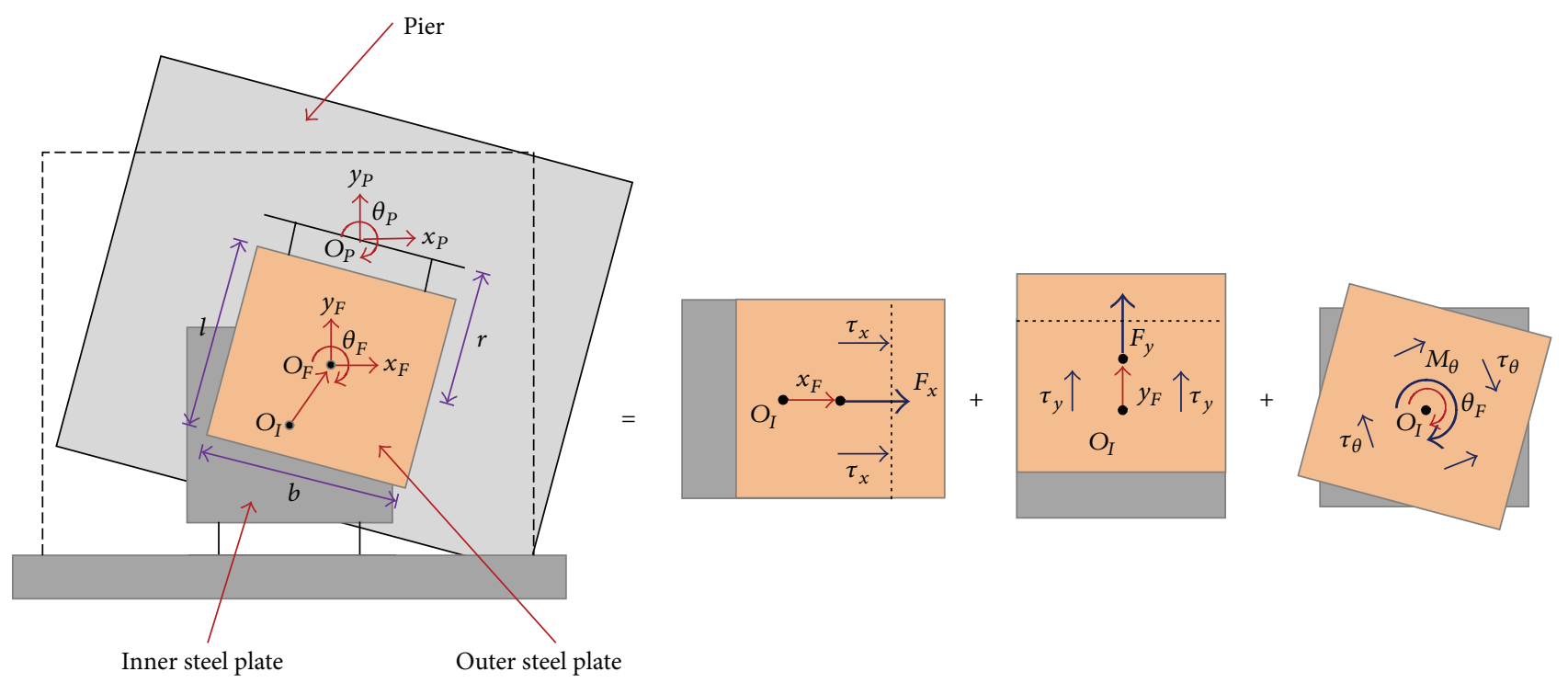

FIgURE 2: Mechanical model of the viscoelastic damper.

Owing to the rotation of the viscoelastic damper, the torque through the damper center can be obtained by the integration of the shear stress multiplying the arm as

$$
M_{\theta}=n \int_{-b / 2}^{b / 2} \int_{-l / 2}^{l / 2} \tau_{\theta} \sqrt{x^{2}+y^{2}} d x d y
$$

where $b$ and $l$ are the width and length of the viscoelastic layer, respectively, and $\tau_{\theta}$ is the shear stress calculated by

$$
\tau_{\theta}=\frac{\sqrt{x^{2}+y^{2}}}{h}\left[\theta_{F} G^{\prime}(\omega)+\dot{\theta}_{F} \frac{G^{\prime \prime}(\omega)}{\omega}\right] .
$$

Substituting (6) into (5), the torque of the viscoelastic damper is then obtained as

$$
M_{\theta}=\frac{\left(b^{2}+l^{2}\right)}{12}\left[\frac{n G^{\prime}(\omega) A}{h} \theta_{F}+\frac{n G^{\prime \prime}(\omega) A}{\omega h} \dot{\theta}_{F}\right]
$$

\section{Analytical Model of the Hybrid System}

3.1. Finite Element Model of the Common Posttensioned Bridge Pier. An effective and accurate analytical model is an important tool for the prediction of the seismic performance of a structure. Various types of analytical models have been developed for self-centering structures with rocking behavior, including the simple lumped plasticity approaches, the finite element method (FEM) with fiber elements, and even 3D FEMs [18]. In this study, the hybrid system of a self-centering bridge pier with a viscoelastic damper is analyzed by using the finite element method based on the OpenSees software application [19]. The schematic diagram of the analytical model of the hybrid system is shown in Figure 3.

Figures 3(a) and 3(b) show the finite element model of the common posttensioned bridge pier. As shown in the figure, the self-centering pier can be modeled by the nonlinear beam-column element for the concrete column and the truss element for the tendons. In this study, the column section is defined with the fiber model using the material model Concrete02, which was developed based on the Kent-ScottPark model [20], for the unconfined cover concrete and the confined core concrete. The constitutive relationship of reinforcement is represented by using the Steel02 material model based on the Giuffre-Menegotto-Pinto model [21]. For the unbonded tendons, initial stress is applied to the truss elements to model the initial tension force of the tendons. Owing to the constraints of the concrete, the lateral DOFs of the truss element are assumed to be coupled with the fiber element, whereas the longitudinal DOFs are free in the vertical direction. At the top of pier, all nodal DOFs of the truss element are constrained to the node of the fiber element to model the anchorages of the posttensioned tendons with the concrete column.

Because of the existence of the joint and critical section between the pier bottom and foundation of the rocking system, it has noncontinuity and incompatibility of the deformation at the opening interface. Generally, there are two different ways to model the gap opening of self-centering structures. The method proposed by Kurama [22] is used in the distributed tensile deformation along the whole length of a pier to simulate local deformation of the opening interface at the joint. To achieve this purpose, the effects of the reinforcement and the tensile strength of the concrete are neglected in the numerical simulation. Actually, this method induces the inaccurate prediction of the local strain and stress of the joint. However, the analysis results of Kurama [22] demonstrated that the global force-displacement relationship and the structural responses of the rocking system can be effectively captured by using the method.

The effectiveness of the viscoelastic damper installed at the bottom of the bridge pier is strongly related to the gap opening and the corresponding local deformation of the 


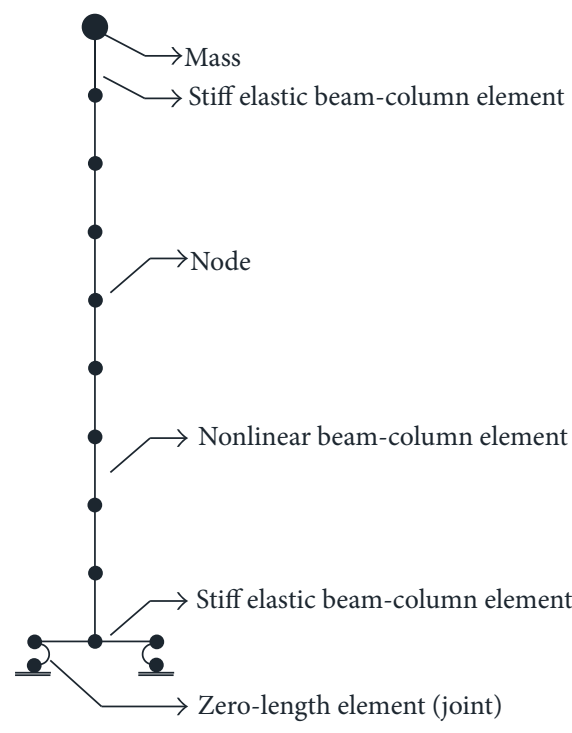

(a)

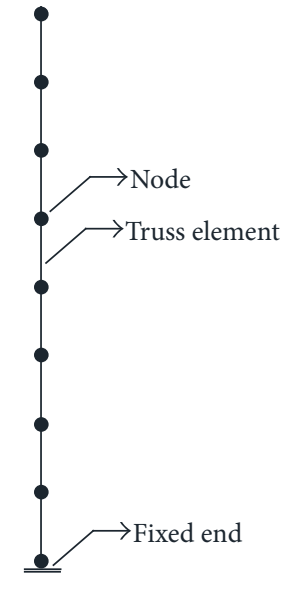

(b)

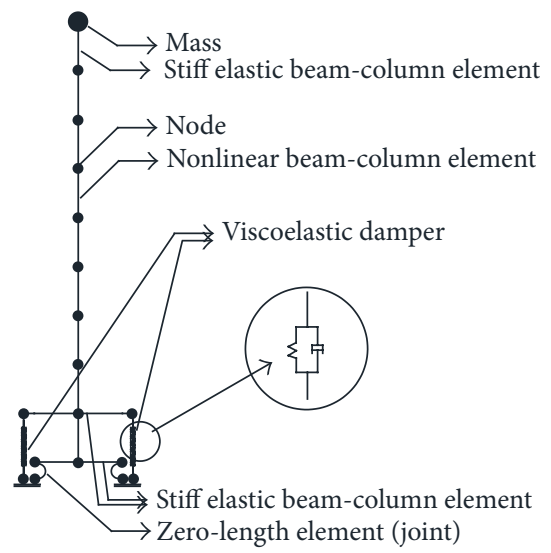

(c)

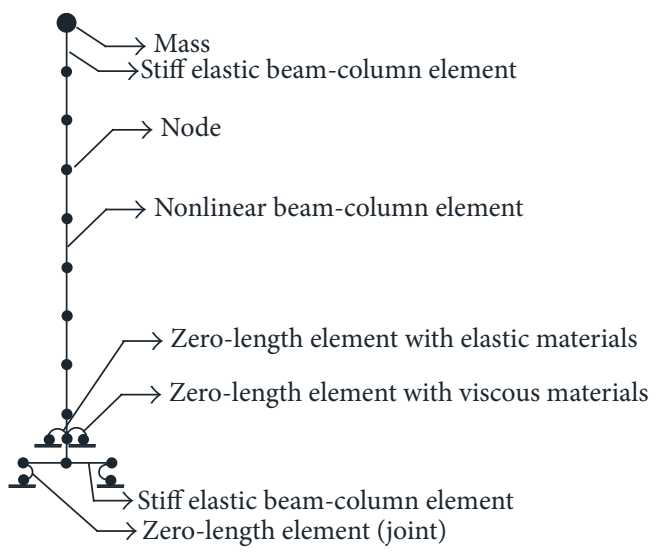

(d)

FIGURE 3: Schematic analytical model of the hybrid system: (a) column of common self-centering pier; (b) tendons; (c) pier with viscoelastic damper with longitudinal direction deformation; (d) pier with viscoelastic damper with transverse direction deformation.

bridge structure. Therefore, the above method is unsuitable for the response analysis of the hybrid system. To model the gap opening and the local deformation, the zero-length element is used in the finite element model. As shown in Figure 3(b), two rigid beam elements are set at the bottom of the column with the length equaling half the beam width. At the end of the rigid beam elements, zero-length elements are used to connect the beams and the foundations. An elastic material tolerating only compression without tension is assigned to the zero-length element. Furthermore, to prevent the penetration of the column into the foundation, a large modulus of elasticity is set for the material of the zerolength elements.

3.2. Finite Element Model of the Posttensioned Pier with Viscoelastic Dampers. Based on the finite element model of the common posttensioned bridge pier, the analytical model of the hybrid system with viscoelastic dampers is also established considering the difference of the propagation direction of the earthquake excitations and the deformation status of the viscoelastic damper. As shown in Figure 3, if the viscoelastic dampers sustain only pure shear deformation, the viscoelastic damper can be easily modeled by the Kelvin model with the elastic spring and dashpot combined in parallel. In OpenSees, the Kelvin model can be represented by two truss elements with elastic and viscous materials, respectively. In this case, the finite element model of the column with a viscoelastic damper is shown in Figure 3(c). In this model, it is also observed that two rigid beam elements are set to consider the installation location of the dampers.

If the earthquake excites the structure in the transverse direction, which induces the translation and rotation of the viscoelastic dampers, the finite element model of the structure with viscoelastic dampers can be modeled by using two zero-length elements, as shown in Figure 3(d), according to the mechanical model of the viscoelastic damper. In this case, one zero-length element with elastic materials is adopted to model the restoring force in the three different DOF directions. The other zero-length element uses the viscous materials to model the damping forces. According 
TABLE 1: Material property of the bridge structure.

\begin{tabular}{|c|c|c|c|c|c|c|c|}
\hline \multicolumn{2}{|c|}{ Concrete } & \multicolumn{2}{|c|}{ Longitudinal reinforcement } & \multirow{2}{*}{$\begin{array}{l}\text { Stirrup } \\
\text { Yield } \\
\text { strength } \\
\text { (MPa) }\end{array}$} & \multicolumn{3}{|c|}{ Posttensioned tendon } \\
\hline $\begin{array}{l}\text { Compressing } \\
\text { strength } \\
(\mathrm{MPa}) \\
\end{array}$ & $\begin{array}{l}\text { Elastic } \\
\text { modulus } \\
(\mathrm{GPa})\end{array}$ & $\begin{array}{c}\text { Yield } \\
\text { strength } \\
(\mathrm{MPa})\end{array}$ & $\begin{array}{c}\text { Elastic } \\
\text { modulus } \\
(\mathrm{GPa})\end{array}$ & & $\begin{array}{c}\text { Yield } \\
\text { strength } \\
(\mathrm{MPa})\end{array}$ & $\begin{array}{c}\text { Ultimate } \\
\text { strength }(\mathrm{MPa})\end{array}$ & $\begin{array}{c}\text { Elastic modulus } \\
(\mathrm{GPa})\end{array}$ \\
\hline 30.0 & 31.5 & 371 & 200 & 282 & 1670 & 1860 & 195.0 \\
\hline
\end{tabular}

FIGURE 4: Bridge configuration and reinforcement.

to (4) and (7), the stiffness and damping of the zero-length element can be determined as $\left(k_{F}, k_{F},\left(b^{2}+l^{2}\right) k_{F} / 12\right)$ and $\left(c_{F}, c_{F},\left(b^{2}+l^{2}\right) c_{F} / 12\right)$, respectively.

\section{Numerical Simulation}

4.1. Description of the Bridge Structure. In this study, a portion of a long highway bridge is selected as the target for the numerical simulation. This highway bridge has a uniform span of $40.0 \mathrm{~m}$. As shown in Figure 4, the superstructure is a single-spine box girder with width of $14.0 \mathrm{~m}$ and height of $2.0 \mathrm{~m}$. The self-weight of the superstructure, including the reinforced concrete box girder, pavement, and auxiliary facilities, is calculated to be $200 \mathrm{kN} / \mathrm{m}$. The highway bridge substructure consists of a single column bent with clear height of $9.0 \mathrm{~m}$ and rectangular cross section of $1.2 \times 1.8 \mathrm{~m}$. The column reinforcement consists of 36 D28 mm longitudinal bars and D16 $\mathrm{mm}$ rectangular stirrup with a pitch of $150 \mathrm{~mm}$. The yield strength of the longitudinal reinforcement and the transverse stirrup are assumed to be $371.0 \mathrm{MPa}$ and $282.0 \mathrm{MPa}$, respectively, and the modulus of elasticity is $200 \mathrm{GPa}$. The concrete compressive strength and the modulus of elasticity are taken as $30.0 \mathrm{MPa}$ and $31.5 \mathrm{GPa}$, respectively. Six $10 \times 140 \mathrm{~mm}^{2}$ strands with yield and ultimate strength of $1670 \mathrm{MPa}$ and $1860 \mathrm{MPa}$, respectively, are used for the unbonded posttensioned tendons. The initial stress of the prestressed tendons is assumed to be $700 \mathrm{MPa}$. The material properties used in this study are summarized in Table 1. According to the above parameters, the reinforcement ratios of the longitudinal rebar and the unbonded posttensioned tendons are calculated to be $1.23 \%$ and $0.39 \%$, respectively. The axial compression ratios generated by the self-weight of the superstructure and the prestressed tendons are computed to be $12.3 \%$ and $9.07 \%$, respectively.

Two viscoelastic dampers are assumed to be attached to the bridge piers to investigate the effectiveness of the devices to improve the seismic performance of the structure.
Generally, it is more feasible to have four viscoelastic dampers all around a pier. However, in order to more clearly investigate the performance of the VE dampers in the two different directions, only two dampers were considered in this study. The seismic performance of the hybrid system is individually analyzed in the longitudinal and transvers directions, respectively, with the installation scheme shown in Figure 1(c). For the VE dampers, the shear modulus and loss modulus of the viscoelastic material are selected to be $2.0 \mathrm{MPa}$ and $3.0 \mathrm{MPa}$, respectively. Each damper is designed to have two layers of viscoelastic materials with thickness of $8.0 \mathrm{~mm}$. The ultimate shear strain at failure status of the viscoelastic material is assumed to be $200 \%$. The length and width of viscoelastic layer are set to be $0.6 \mathrm{~m}$. A finite element model of the hybrid system is built by using the OpenSees software package and the method introduced above. Before the analysis, the initial stress and the gravity load are first applied to the posttensioned tendons and the columns, respectively, to achieve the initial static status of the structure.

4.2. Cyclic Behavior. The hysteretic characteristic of bridge piers is generally able to capture the backbone skeleton loading curves and energy dissipation of the structural components. With the finite element model, the cyclic relationship between the base shear force and the top displacement of the common posttensioned bridge pier is analyzed and shown in Figure 5 for the weak (longitudinal) and strong axis (transverse) directions, respectively. From the figure, it is observed that the cyclic behavior of the posttensioned bridge structure is nearly nonlinear elastic owing to the separation of the joint between the pier and foundation and the action of the posttensioned tendons. This simulation result coincides well with the test results of [13]. The extremely narrow hysteresis loops reveal that the energy dissipation of the structure is very small.

For comparison, the hysteretic curves of the posttensioned bridge pier equipped with viscoelastic dampers 


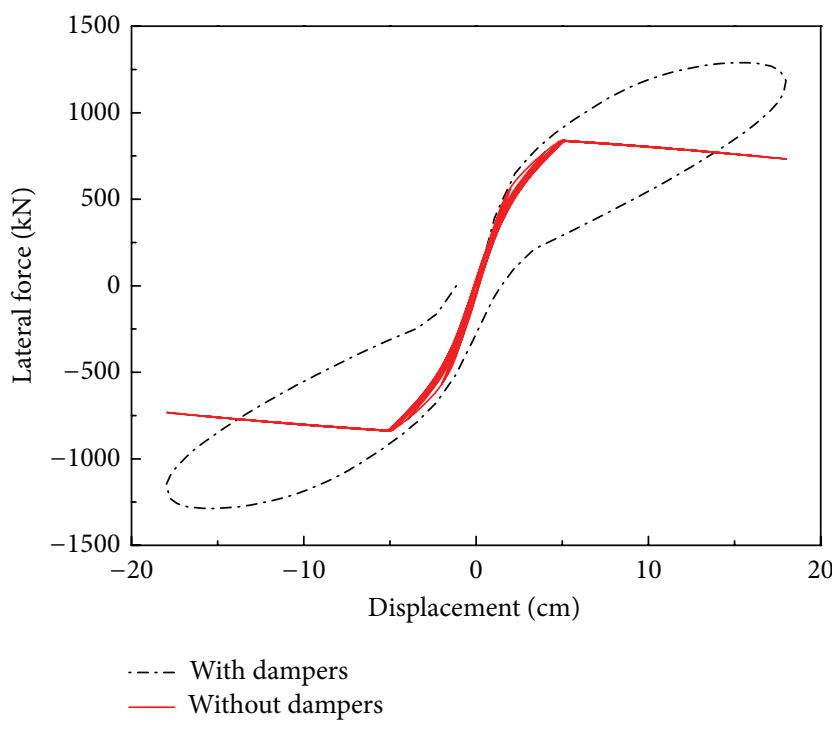

(a)

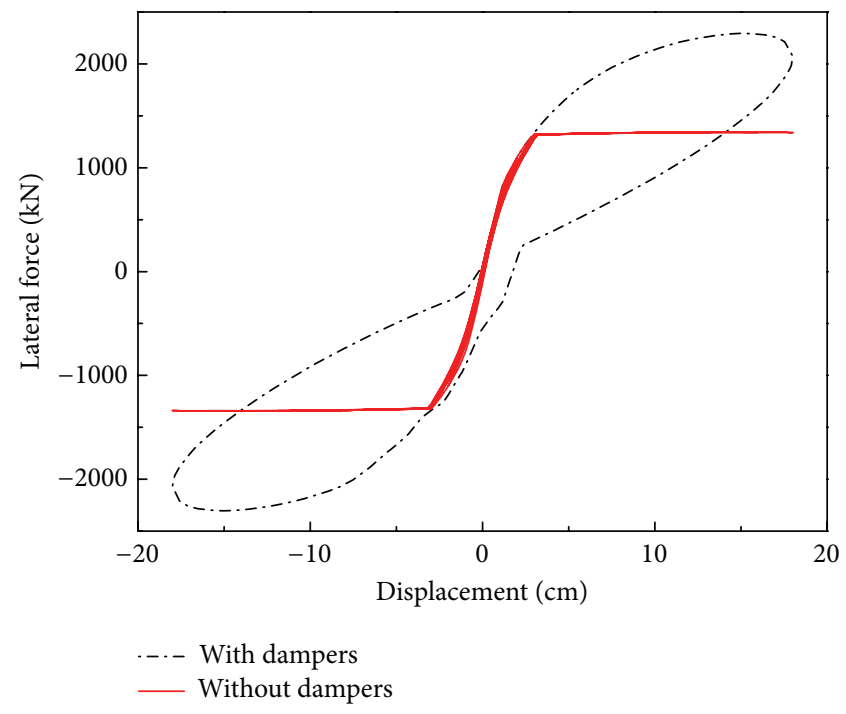

(b)

FIGURE 5: Hysteretic curves of the bridge pier: (a) weak axis; (b) strong axis.

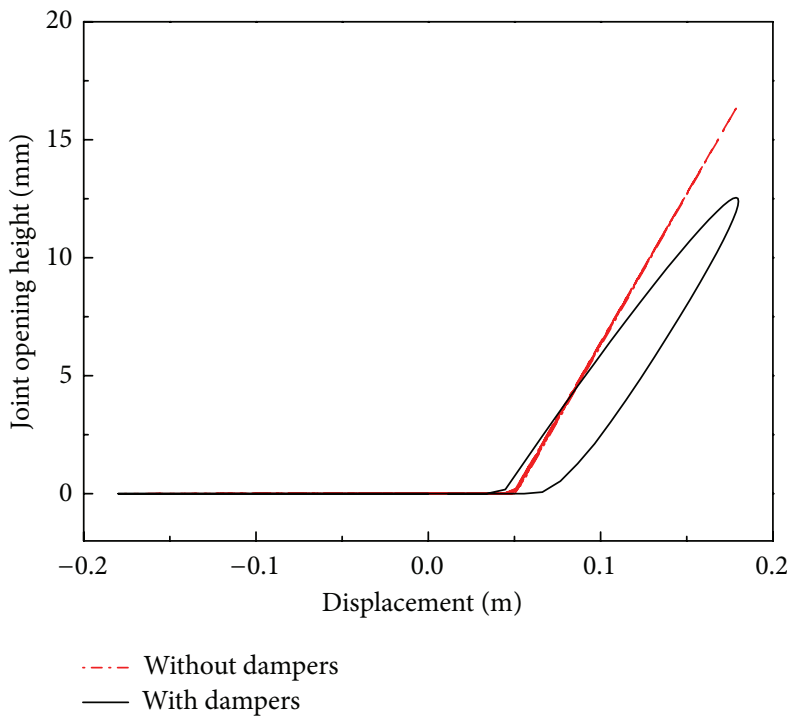

(a)

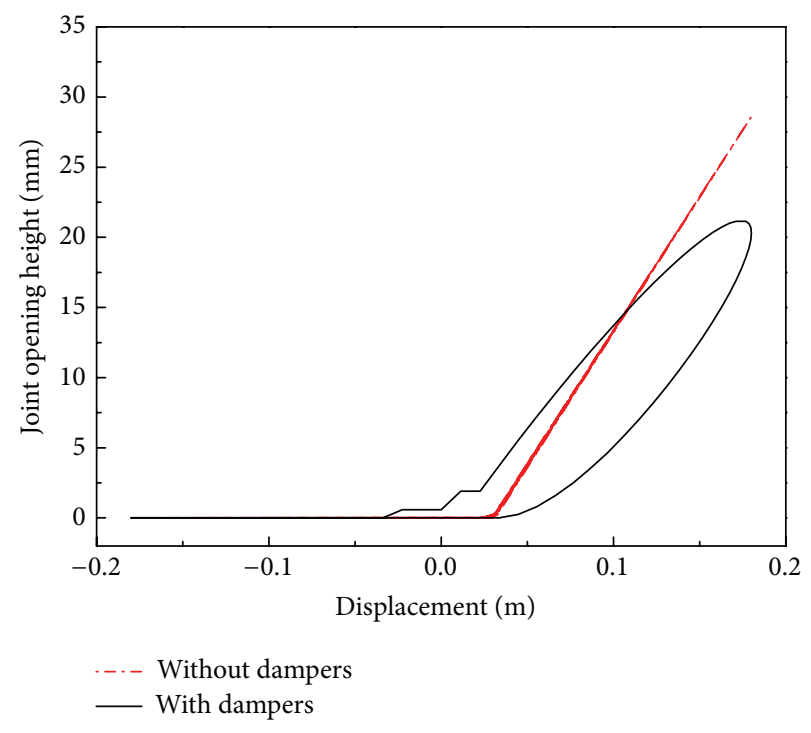

(b)

Figure 6: Gap opening height at the left side joint versus lateral top displacement of the pier: (a) longitudinal direction; (b) transverse direction.

are also shown in Figure 5. In this simulation, harmonic lateral displacement is applied at the top pier with frequency of $1.0 \mathrm{~Hz}$ to consider the damping force provided by the viscoelastic damper. It can be observed from the figure that the lateral force of the common posttensioned bridge pier gradually decreases with increasing gap opening of the noncontinuous interface at the bottom. However, with the installation of the viscoelastic damper, the hysteresis loop of the hybrid system becomes fuller than the common posttensioned pier because the viscoelastic damper provides additional damping to the structure.
The gap opening height at the left side joint is shown in Figure 6 for the structure subjected to cyclic loadings. It can be observed that the opening of the gap interface appears only under the half cycle of harmonic excitation for each side. For the same maximum lateral displacement of $18 \mathrm{~cm}$ at the top pier, the maximum opening height is reduced from $16.5 \mathrm{~mm}$ to $12.5 \mathrm{~mm}$ and from $28.6 \mathrm{~mm}$ to $21.2 \mathrm{~mm}$ for the longitudinal and transverse directions, respectively, representing reductions of $24.2 \%$ and $25.9 \%$, after the installation of the viscoelastic dampers. Moreover, Figure 7 shows the relationship between the lateral top displacement and the tension force of the tendons. It can be 
TABLE 2: Earthquake records used for the time history analysis.

\begin{tabular}{lcccc}
\hline Number & Event & Station & PGA (g) & Soil \\
\hline 1 & Northridge 1994 & Burbank & 0.120 & B \\
2 & Loma Prieta 1989 & Coyote Lake Dam & 0.179 & B \\
3 & San Fernando 1971 & Old Ridge Route & 0.324 & B \\
\hline
\end{tabular}

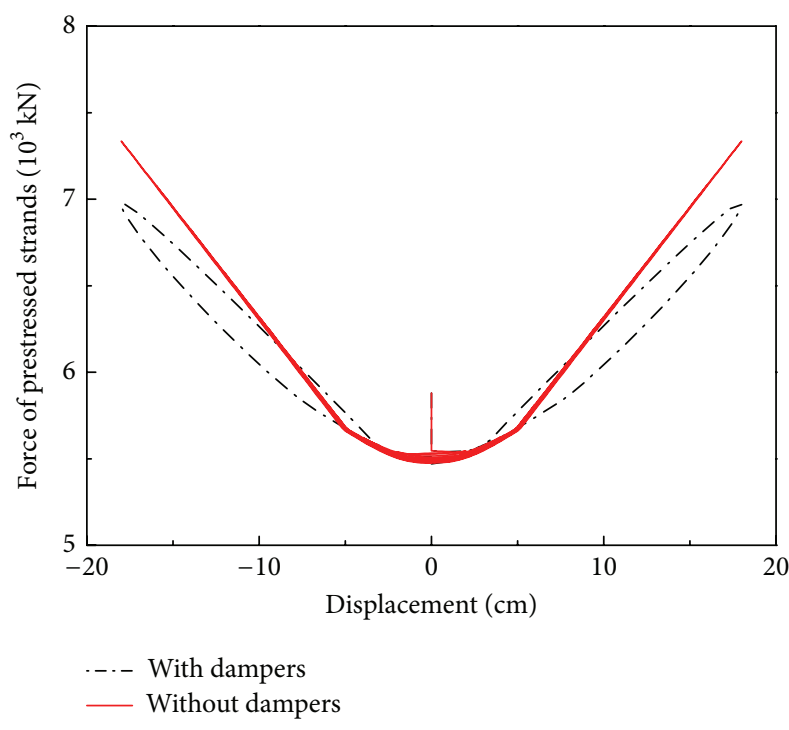

(a)

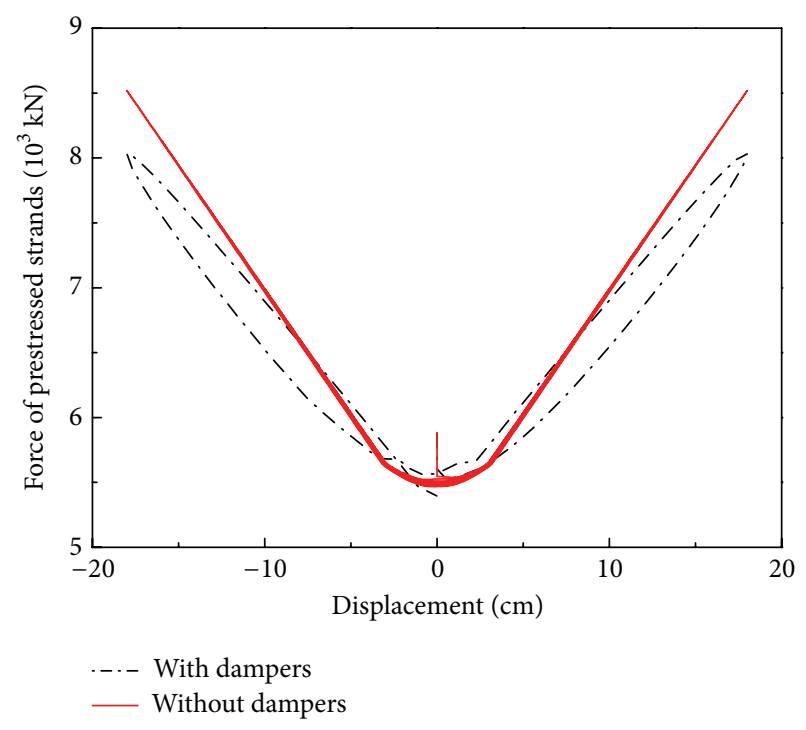

(b)

FIGURE 7: Tension force of the tendons versus lateral top displacement of the pier: (a) longitudinal direction; (b) transverse direction.

found that the initial stress of the tendons is set as $700 \mathrm{MPa}$ with a tension force of approximately $5.88 \times 10^{3} \mathrm{kN}$. During the analysis, the tension force of the tendons is reduced to $5.55 \times 10^{3} \mathrm{kN}$ owing to the loss of prestress under the gravity loadings. With increasing lateral top deformation, the tension forces are also approximately increased linearly. When the lateral deformation is increased to $18.0 \mathrm{~cm}$, the tension forces of the tendons of the common posttensioned bridge pier are also increased to $7.37 \times 10^{3} \mathrm{kN}$ and $8.57 \times 10^{3} \mathrm{kN}$ in the longitudinal and transverse directions, respectively, with corresponding tension stress of $877 \mathrm{MPa}$ and $1020 \mathrm{MPa}$. With the installation of the viscoelastic dampers, the tension forces slightly decrease to $6.98 \times 10^{3} \mathrm{kN}$ and $8.04 \times 10^{3} \mathrm{kN}$, respectively, with corresponding tension stress of $831 \mathrm{MPa}$ and $957 \mathrm{MPa}$.

4.3. Time History Analysis. To further investigate the effectiveness of the viscoelastic damper, a nonlinear time history analysis was performed on the structure using the established finite element model. Three earthquake records are selected as the inputs of the ground motion. Those earthquake records satisfy the response spectrum of ground type B in EC8. During the analysis, all peak ground acceleration (PGA) values of the earthquake records are scaled to $620 \mathrm{gal}$ for the severe earthquake with seismic intensity 9 according to the Code for Seismic Design of Urban Bridges of China (CJJ1662011) [23]. The basic information of those earthquake records is listed in Table 2.
As an example, the dynamic responses of the structures under the Northridge earthquake are comprehensively analyzed in the following. The acceleration signals of the Northridge earthquake record are shown in Figure 8(a). Through the numerical simulation, Figure 9 shows the time history of the displacement of the bridge deck under the Northridge earthquake record. It can be seen from the figure that the maximum displacement of the uncontrolled bridge is $12.0 \mathrm{~cm}$ in the longitudinal direction. With the installation of the viscoelastic dampers, the peak displacement is reduced to $9.5 \mathrm{~cm}$, a reduction of $20.8 \%$. The RMS value of the peak displacement is also reduced from $3.9 \mathrm{~cm}$ to $3.6 \mathrm{~cm}$, a reduction of $7.7 \%$. In the transverse direction, the maximum displacement and RMS value of the bridge deck are found to be $12.7 \mathrm{~cm}$ and $3.6 \mathrm{~cm}$, respectively. For the hybrid system with viscoelastic dampers, they are reduced to $10.8 \mathrm{~cm}$ and $2.8 \mathrm{~cm}$, respectively, reductions of $15.0 \%$ and $22.2 \%$.

To further investigate the effectiveness of the hybrid system, Figure 10 shows the time history of the bottom shear of the bridge. It can be seen from the figure that the bottom shear is reduced from $1246 \mathrm{kN}$ to $1133 \mathrm{kN}$ and from $2443 \mathrm{kN}$ to $1860 \mathrm{kN}$ for the longitudinal and transverse directions, respectively, with the installation of the viscoelastic dampers. Figure 11 shows the acceleration responses of the bridge deck with and without viscoelastic damper. It is observed from the figure that the peak acceleration responses are reduced from $7.12 \mathrm{~m} / \mathrm{s}^{2}$ to $7.03 \mathrm{~m} / \mathrm{s}^{2}$ and from $7.64 \mathrm{~m} / \mathrm{s}^{2}$ to $7.23 \mathrm{~m} / \mathrm{s}^{2}$ for the longitudinal and transverse directions, respectively, 


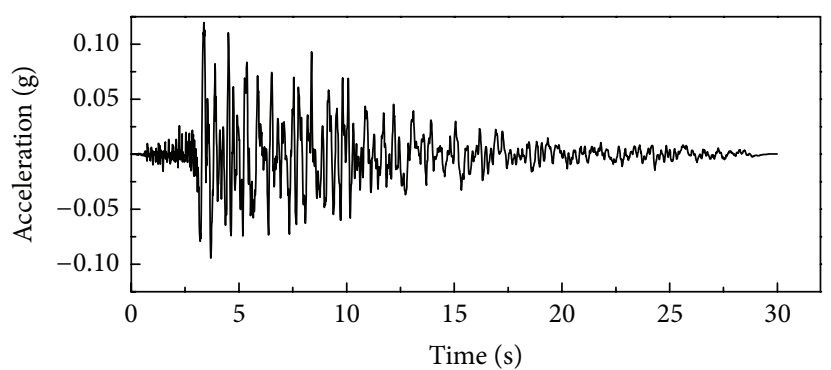

(a)

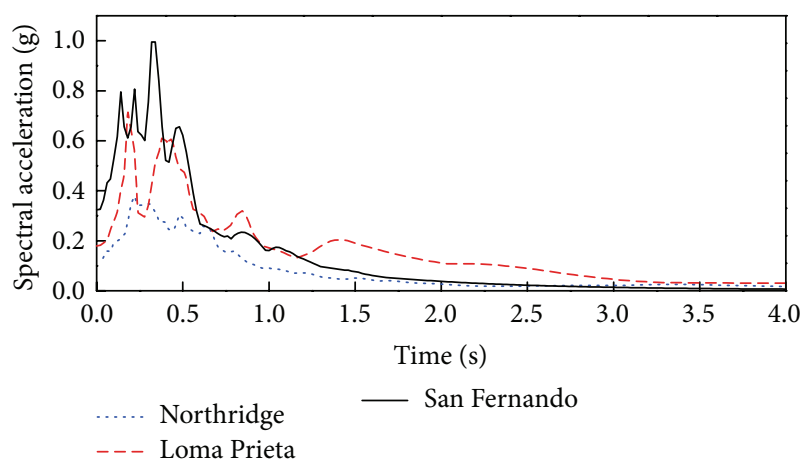

(b)

FIGURE 8: Earthquake record: (a) acceleration signal of the 1994 Northridge earthquake; (b) response spectra.

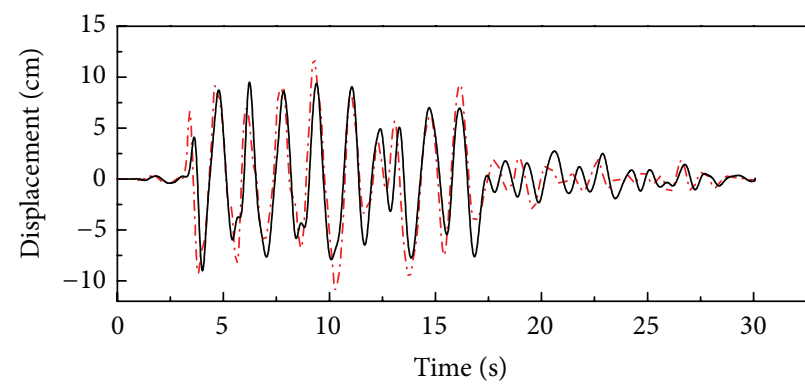

-.- Without dampers

— With dampers

(a)

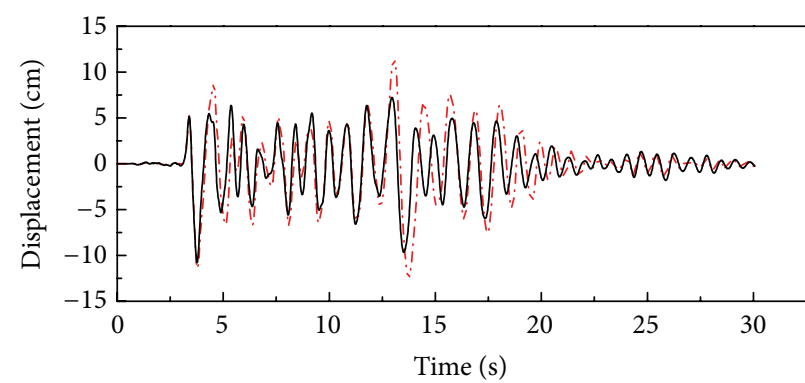

-.- Without dampers

— With dampers

FIGURE 9: Time histories of the displacement of the bridge deck: (a) longitudinal direction; (b) transverse direction.

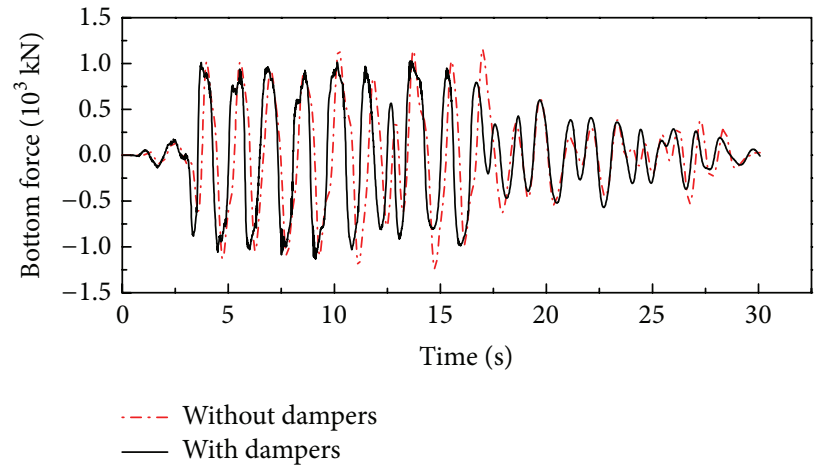

(a)

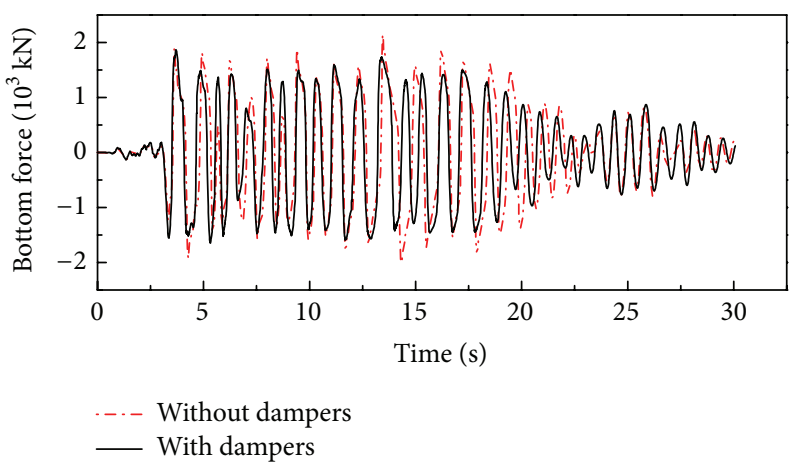

(b)

FIGURE 10: Time histories of the bottom shear: (a) longitudinal direction; (b) transverse direction.

with the installation of the viscoelastic dampers. From the analysis results, it can be found that the effectiveness of viscoelastic dampers is not significant for the mitigation of the acceleration responses. The reason of this phenomenon is due to the increase of the natural frequency of the structure with the installation of the viscoelastic dampers, which provided additional stiffness on the structures.

The tension force of the posttensioned tendons is also shown in Figure 12. It is seen in the figure that the maximum tension force is slightly decreased from $6562 \mathrm{kN}$ to $6361 \mathrm{kN}$, a reduction of $3.06 \%$, in the longitudinal direction. In the transverse direction, the tension force is reduced from $7522 \mathrm{kN}$ to $6913 \mathrm{kN}$, a reduction of $8.10 \%$. For the gap opening of the joint, Figure 13 shows the time histories of the opening height of the left side joint. It can be observed that the joint opening height is reduced from $8.8 \mathrm{~mm}$ to $5.5 \mathrm{~mm}$ and from $16.3 \mathrm{~mm}$ to $6.3 \mathrm{~mm}$ for the longitudinal and transverse directions, respectively, with the installation of the viscoelastic dampers. 


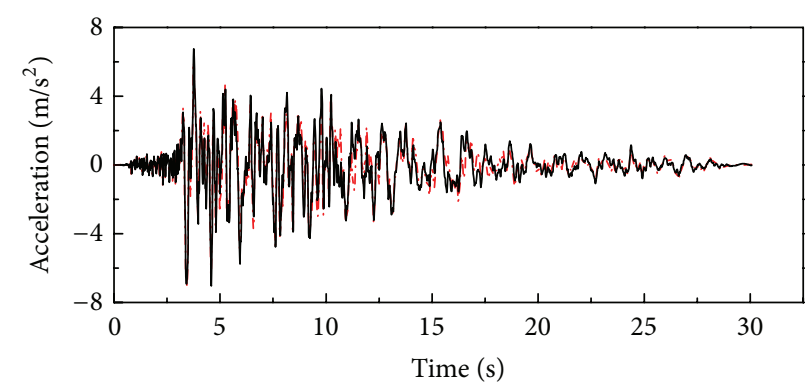

Without dampers

With dampers

(a)

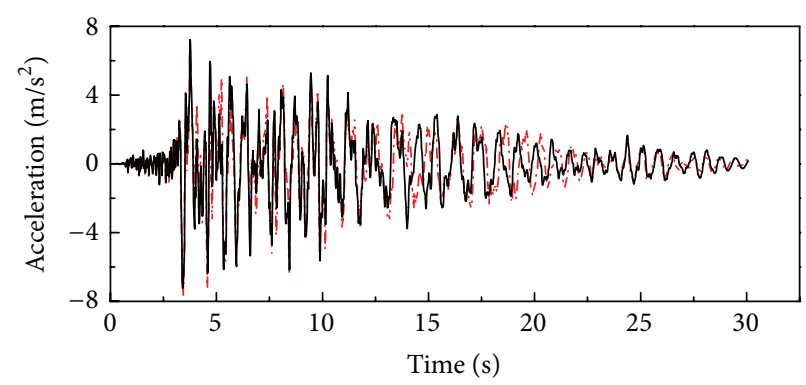

-..- Without dampers

— With dampers

FIGURE 11: Time histories of the acceleration of the bridge deck: (a) longitudinal direction; (b) transverse direction.

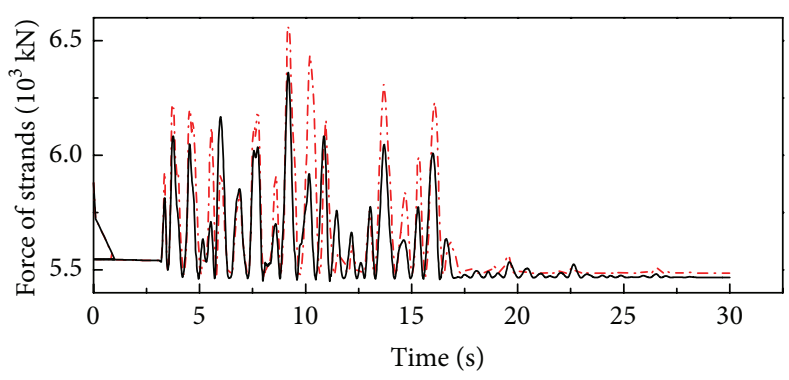

Without dampers

With dampers

(a)

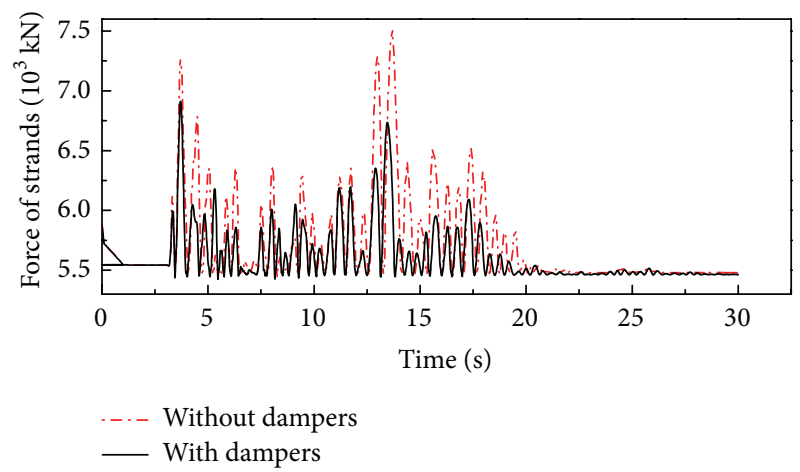

(b)

FIGURE 12: Tension force of the tendons: (a) longitudinal direction; (b) transverse direction.

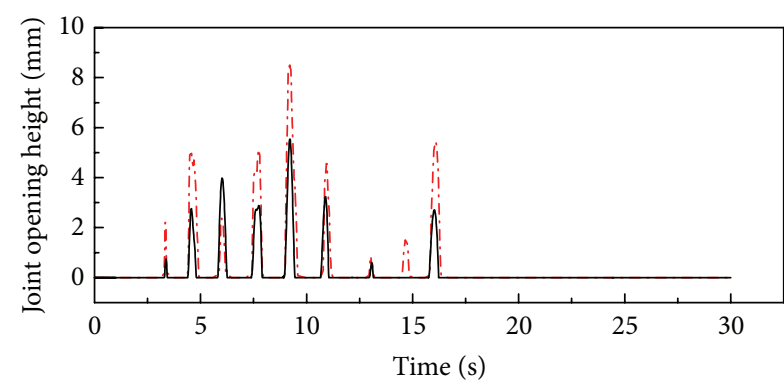

Without dampers

With dampers

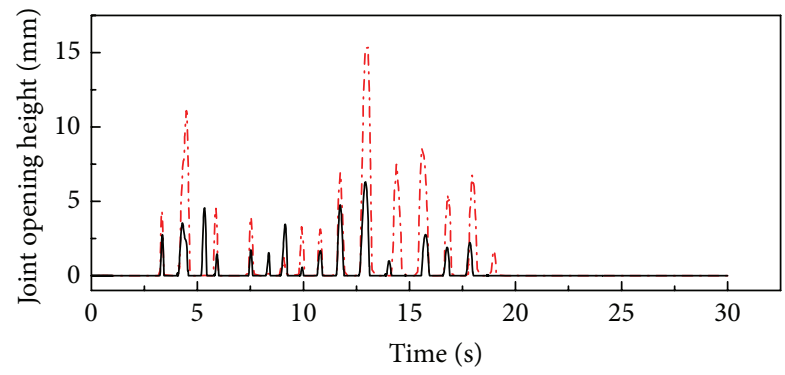

Without dampers

With dampers

(a)

(b)

FIGURE 13: Opening height of the joint: (a) longitudinal direction; (b) transverse direction.

For comparison, the maximum and RMS responses, including the displacement and acceleration of the bridge deck and the bottom base shear, of the common posttensioned bridge and hybrid systems with viscoelastic dampers are summarized in Tables 3-5. It should be mentioned that the maximum and RMS values of the base shears listed in Table 5 are only the lateral load resisted by the concrete pier and tendons, and the base shears sustained by the VE dampers are not included for the convenience of comparison with the uncontrolled structure. From those tables, it can be seen that the viscoelastic damper can effectively reduce the structural dynamic responses and improve the seismic performance of the hybrid system.

\section{Conclusions}

This paper proposed a passive control approach for a posttensioned self-centering bridge pier using the viscoelastic 
TABLE 3: Maximum and RMS values of the displacement responses of the bridge deck $(\mathrm{cm})$.

\begin{tabular}{|c|c|c|c|c|c|c|}
\hline Direction & Earthquake record & $\begin{array}{c}\text { Maximum } \\
\text { (without } \\
\text { damper) }\end{array}$ & $\begin{array}{l}\text { RMS (without } \\
\text { damper) }\end{array}$ & $\begin{array}{l}\text { Maximum (with } \\
\text { damper) }\end{array}$ & $\begin{array}{l}\text { RMS (with } \\
\text { damper) }\end{array}$ & $\begin{array}{c}\text { Reduction of } \\
\text { maximum } \\
(\%)\end{array}$ \\
\hline \multirow{3}{*}{ Longitudinal } & Northridge & 12.0 & 3.9 & 9.5 & 3.6 & 20.8 \\
\hline & Loma Prieta & 44.9 & 10.9 & 38.5 & 6.8 & 14.3 \\
\hline & San Fernando & 6.6 & 2.2 & 6.3 & 2.1 & 4.5 \\
\hline \multirow{3}{*}{ Transverse } & Northridge & 12.7 & 3.6 & 10.8 & 2.8 & 15.0 \\
\hline & Loma Prieta & 32.5 & 4.8 & 21.1 & 3.8 & 35.1 \\
\hline & San Fernando & 7.8 & 2.1 & 6.4 & 1.7 & 18.0 \\
\hline
\end{tabular}

TABLE 4: Maximum and RMS values of the acceleration responses of the bridge deck $\left(\mathrm{m} / \mathrm{s}^{2}\right)$.

\begin{tabular}{|c|c|c|c|c|c|c|}
\hline Direction & Earthquake record & $\begin{array}{c}\text { Maximum } \\
\text { (without } \\
\text { damper) }\end{array}$ & $\begin{array}{l}\text { RMS (without } \\
\text { damper) }\end{array}$ & $\begin{array}{l}\text { Maximum (with } \\
\text { damper) }\end{array}$ & $\begin{array}{l}\text { RMS (with } \\
\text { damper) }\end{array}$ & $\begin{array}{c}\text { Reduction of } \\
\text { maximum } \\
(\%)\end{array}$ \\
\hline \multirow{3}{*}{ Longitudinal } & Northridge & 7.12 & 1.33 & 7.03 & 1.36 & 1.26 \\
\hline & Loma Prieta & 7.40 & 1.15 & 7.95 & 1.16 & -7.43 \\
\hline & San Fernando & 5.62 & 1.12 & 5.68 & 1.11 & -1.07 \\
\hline \multirow{3}{*}{ Transverse } & Northridge & 7.64 & 1.66 & 7.23 & 1.69 & 5.37 \\
\hline & Loma Prieta & 7.96 & 1.30 & 8.37 & 1.29 & -5.15 \\
\hline & San Fernando & 7.66 & 1.35 & 8.33 & 1.26 & -8.75 \\
\hline
\end{tabular}

TABLE 5: Maximum and RMS values of the base shear of the concrete pier $(\mathrm{kN})$.

\begin{tabular}{|c|c|c|c|c|c|c|}
\hline Direction & Earthquake record & $\begin{array}{c}\text { Maximum } \\
\text { (without } \\
\text { damper) }\end{array}$ & $\begin{array}{l}\text { RMS (without } \\
\text { damper) }\end{array}$ & $\begin{array}{l}\text { Maximum (with } \\
\text { damper) }\end{array}$ & $\begin{array}{l}\text { RMS (with } \\
\text { damper) }\end{array}$ & $\begin{array}{c}\text { Reduction of } \\
\text { maximum } \\
(\%)\end{array}$ \\
\hline \multirow{3}{*}{ Longitudinal } & Northridge & 1246 & 499 & 1133 & 524 & 9.1 \\
\hline & Loma Prieta & 1706 & 457 & 1465 & 493 & 14.1 \\
\hline & San Fernando & 1072 & 444 & 934 & 441 & 12.9 \\
\hline \multirow{3}{*}{ Transverse } & Northridge & 2443 & 911 & 1860 & 878 & 23.9 \\
\hline & Loma Prieta & 2684 & 680 & 2243 & 723 & 16.4 \\
\hline & San Fernando & 1797 & 803 & 1576 & 715 & 12.3 \\
\hline
\end{tabular}

damper to improve the seismic performance of this type of structure. The configuration and installation scheme of the devices are developed, and the mechanical models are established considering the deformation status of the dampers under longitudinal and transverse earthquake ground motions. A finite element model of the common posttensioned bridge and the structure with viscoelastic dampers are also built by using the OpenSees finite element software package. The conclusions of this study are summarized as follows:

(1) With the installation of the viscoelastic damper, the energy dissipation device can provide additional stiffness and damping to the structure. In the longitudinal direction, it performs as a conventional viscoelastic damper with only pure shear deformation. When the earthquake excitation is applied to the structure in the transverse direction, the rotation effects of the viscoelastic dampers should be considered in the analysis.
(2) The zero-length element is more suitable for the joint simulation of the posttensioned bridge pier to achieve the local deformation analysis.

(3) From the cyclic behavior, it can be found that the viscoelastic damper will significantly increase the strength and the damping of the posttensioned bridge pier.

(4) The time history analysis indicates that the viscoelastic damper can effectively reduce the structural dynamic responses and improve the seismic performance of the hybrid system.

\section{Competing Interests}

The authors declare that they have no competing interests.

\section{Acknowledgments}

The financial support from the National Natural Science Foundation of China with Grant no. 51222808 and the 
Fundamental Research Funds for the Central Universities of China with Grant no. HIT.BRETIV.201320 are greatly appreciated by the authors.

\section{References}

[1] M. J. N. Priestley, G. M. Calvi, and M. J. Kowalsky, DisplacementBased Seismic Design of Structures, IUSS Press, Pavia, Italy, 2007.

[2] M. J. N. Priestley and J. R. Tao, "Seismic response of precast prestressed concrete frames with partially debonded tendons," PCI Journal, vol. 38, no. 1, pp. 58-69, 1993.

[3] W.-P. Kwan and S. L. Billington, "Unbonded posttensioned concrete bridge piers. I. Monotonic and cyclic analyses," Journal of Bridge Engineering, vol. 8, no. 2, pp. 92-101, 2003.

[4] A. Palermo and S. Pampanin, "Enhanced seismic performance of hybrid bridge systems: comparison with traditional monolithic solutions," Journal of Earthquake Engineering, vol. 12, no. 8, pp. 1267-1295, 2008.

[5] J. T. Hewes and M. J. N. Priestley, Seismic Design and Performance of Precast Concrete Segmental Bridge Columns, Department of Structural Engineering, University of California, San Diego, Calif, USA, 2002.

[6] C.-C. Chou and Y.-C. Chen, "Cyclic tests of post-tensioned precast CFT segmental bridge columns with unbonded strands," Earthquake Engineering and Structural Dynamics, vol. 35, no. 2, pp. 159-175, 2006.

[7] A. V. Pinto, P. Pegon, G. Magonette, and G. Tsionis, "Pseudodynamic testing of bridges using non-linear substructuring," Earthquake Engineering and Structural Dynamics, vol. 33, no. 11, pp. 1125-1146, 2004.

[8] W.-P. Kwan and S. L. Billington, "Unbonded posttensioned concrete bridge piers. II: seismic analyses," Journal of Bridge Engineering, vol. 8, no. 2, pp. 102-111, 2003.

[9] C.-T. Cheng, "Shaking table tests of a self-centering designed bridge substructure," Engineering Structures, vol. 30, no. 12, pp. 3426-3433, 2008.

[10] H. I. L. Jeong, J. Sakai, and S. A. Mahin, Shaking Table Tests and Numerical Investigation of Self-Centering Reinforced Concrete Bridge Columns, Pacific Earthquake Engineering Research Center, University of California, Berkeley, Calif, USA, 2008.

[11] J. M. Wacker, D. G. Hieber, J. F. Stanton, and M. O. Eberhard, Design of Precast Concrete Piers for Rapid Bridge Construction in Seismic Regions, Washington State Transportation Center, University of Washington, Seattle, Wash, USA, 2005.

[12] W. K. Lee and S. L. Billington, "Performance-based earthquake engineering assessment of a self-centering, post-tensioned concrete bridge system," Earthquake Engineering and Structural Dynamics, vol. 40, no. 8, pp. 887-902, 2011.

[13] A. Palermo, S. Pampanin, and D. Marriott, "Design, modeling, and experimental response of seismic resistant bridge piers with posttensioned dissipating connections," Journal of Structural Engineering, vol. 133, no. 11, pp. 1648-1661, 2007.

[14] Y.-C. Ou, M.-S. Tsai, K.-C. Chang, and G. C. Lee, "Cyclic behavior of precast segmental concrete bridge columns with high performance or conventional steel reinforcing bars as energy dissipation bars," Earthquake Engineering and Structural Dynamics, vol. 39, no. 11, pp. 1181-1198, 2010.

[15] D. Marriott, S. Pampanin, and A. Palermo, "Quasi-static and pseudo-dynamic testing of unbonded post-tensioned rocking bridge piers with external replaceable dissipaters," Earthquake
Engineering and Structural Dynamics, vol. 38, no. 3, pp. 331-354, 2009.

[16] D. Marriott, S. Pampanin, and A. Palermo, "Biaxial testing of unbonded post-tensioned rocking bridge piers with external replacable dissipaters," Earthquake Engineering and Structural Dynamics, vol. 40, no. 15, pp. 1723-1741, 2011.

[17] M. A. ElGawady and A. Sha'lan, "Seismic behavior of selfcentering precast segmental bridge bents," Journal of Bridge Engineering, vol. 16, no. 3, pp. 328-339, 2011.

[18] H. Dawood, Seismic Behavior and Design of Segmental Precast Post-tensioned Concrete Piers, Department of Civil Engineering, Washington State University, 2010.

[19] M. Silvia, M. Frank, and H. Michael, Open System for Earthquake Engineering Simulation User Manual, Pacific Earthquake Engineering Research Center, Berkeley, University of California, Berkeley, Calif, USA, 2005.

[20] E. Spacone, F. C. Filippou, and F. F. Taucer, "Fibre beam-column model for non-linear analysis of R/C frames: part I. Formulation," Earthquake Engineering and Structural Dynamics, vol. 25, no. 7, pp. 711-725, 1996.

[21] L. P. Saenz, "Discussion of "equation for the stress-strain curve of concrete" by P. Desai, and S. Krishnan," American Concrete Institute Journal, vol. 61, no. 9, pp. 1229-1235, 1964.

[22] Y. C. Kurama, "Hybrid post-tensioned precast concrete walls for use in seismic regions," PCI Journal, vol. 47, no. 5, pp. 36-59, 2002.

[23] "Seismic design of urban bridges of China," Tech. Rep. CJJ1662011, Ministry of Housing and Urban-Rural Development of the People's Republic of China, 2011. 


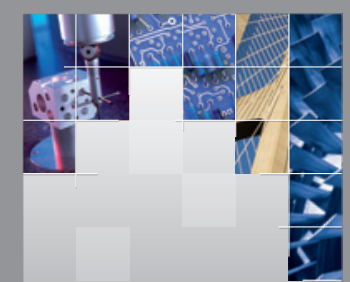

\section{Enfincering}
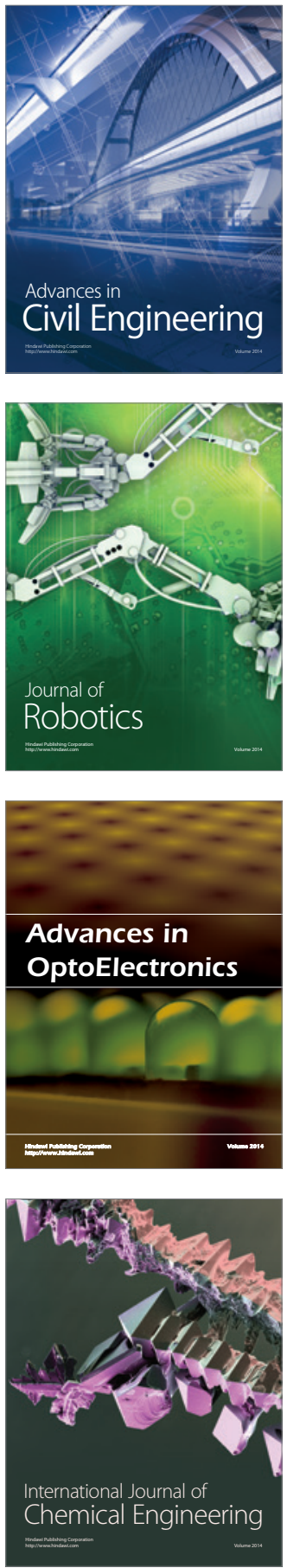

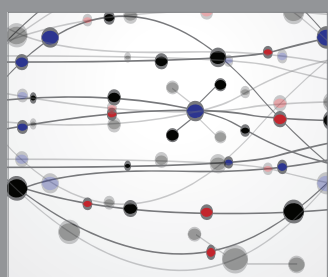

The Scientific World Journal

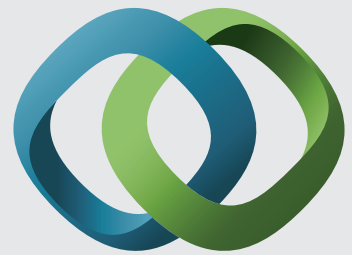

\section{Hindawi}

Submit your manuscripts at

http://www.hindawi.com
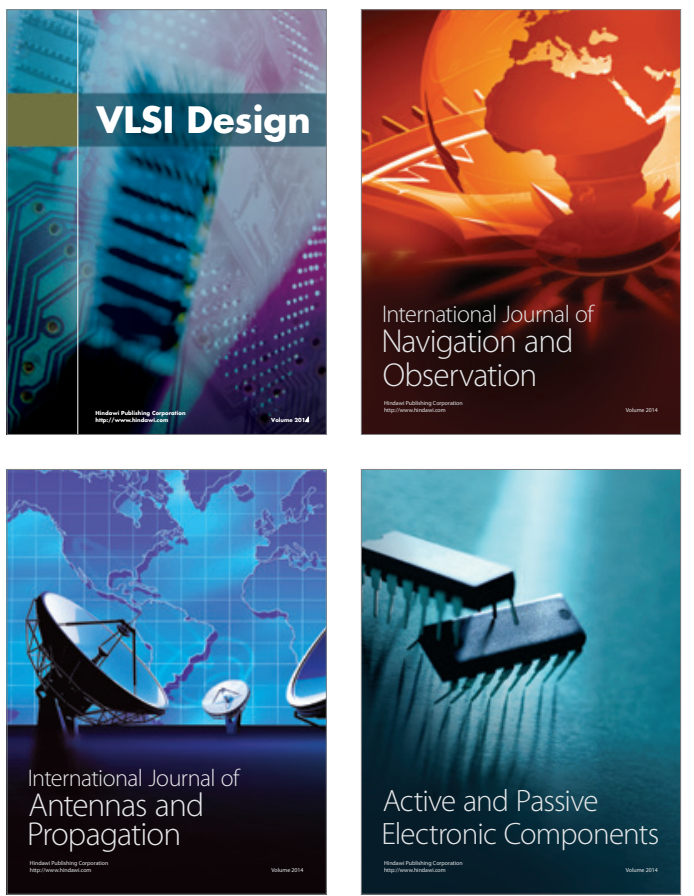
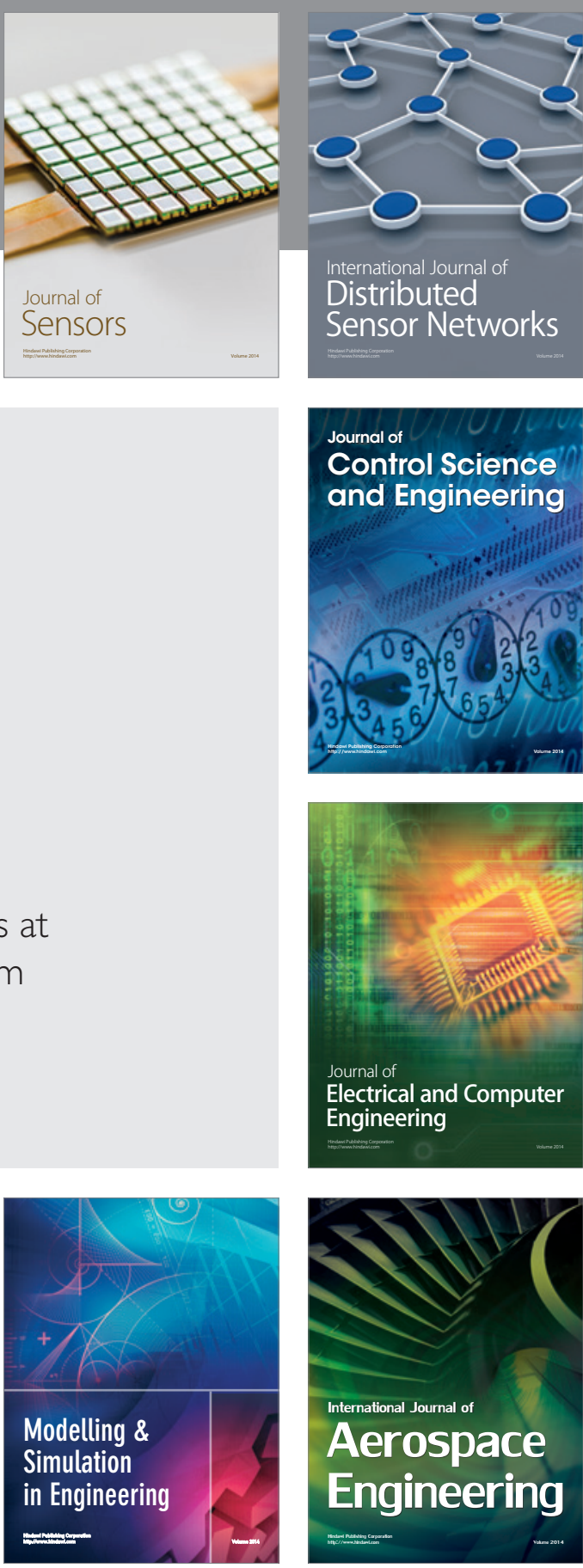

International Journal of

Distributed

Sensor Networks

Journal of

Control Science

and Engineering
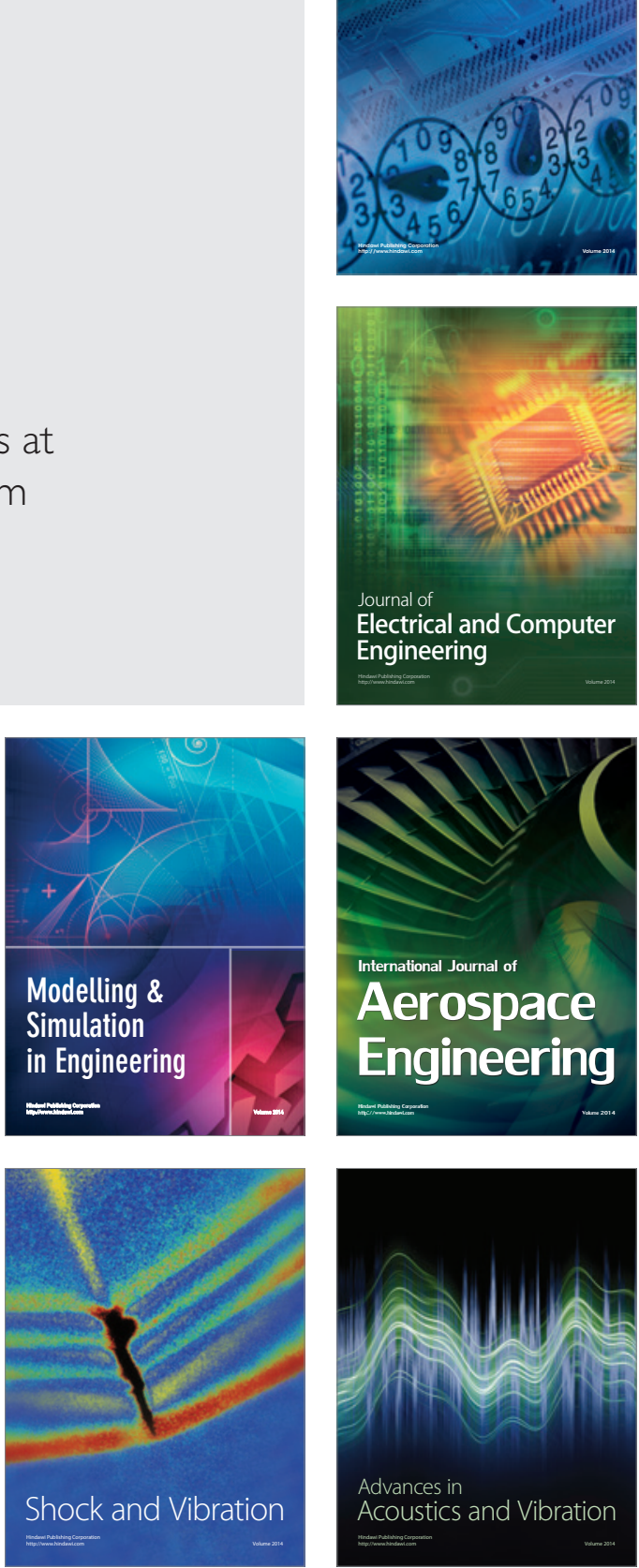